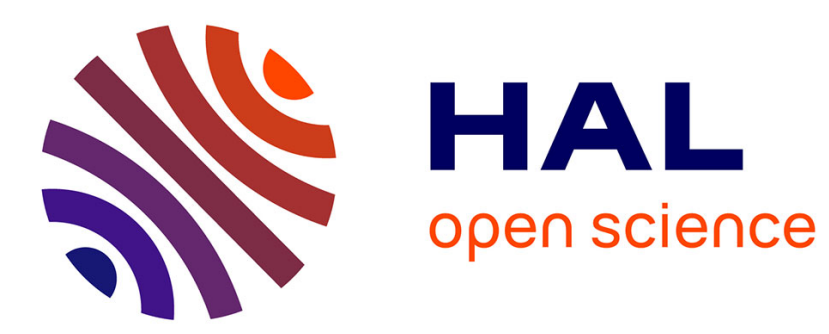

\title{
Shrinkage of the Gelatinous Layer of Poplar and Beech Tension Wood
}

Bruno Clair, Bernard Thibaut

\section{To cite this version:}

Bruno Clair, Bernard Thibaut. Shrinkage of the Gelatinous Layer of Poplar and Beech Tension Wood. IAWA Journal, 2001, 22, pp.121-131. 10.1163/22941932-90000273 . hal-00004542

\section{HAL Id: hal-00004542 \\ https://hal.science/hal-00004542}

Submitted on 22 Mar 2005

HAL is a multi-disciplinary open access archive for the deposit and dissemination of scientific research documents, whether they are published or not. The documents may come from teaching and research institutions in France or abroad, or from public or private research centers.
L'archive ouverte pluridisciplinaire HAL, est destinée au dépôt et à la diffusion de documents scientifiques de niveau recherche, publiés ou non, émanant des établissements d'enseignement et de recherche français ou étrangers, des laboratoires publics ou privés. 


\title{
SHRINKAGE OF THE GELATINOUS LAYER OF POPLAR AND BEECH TENSION WOOD
}

\author{
by
}

\author{
Bruno Clair \& Bernard Thibaut
}

LMGC - Bois, Université Montpellier II, CC 081, Place E. Bataillon, 34095 Montpellier, France (e-mail: clair@lmgc.univ-montp2.fr).

Published in IAWA Journal, Vol. 22 (2), 2001: 121-131

\section{SUMMARY}

Macroscopic longitudinal shrinkage in beech or poplar tension wood is higher than in normal wood. This shrinkage is the result of cell walls layers mechanical interactions. In order to complete the basic data with a view to modelling the cell wall, we are interested in shrinkage differences between cell wall layers and especially of Glayer in poplar and beech. Wood samples in green condition are cut with a razor blade, and then dried before observation. SEM observation shows longitudinal shrinkage much more important in gelatinous layer than in other layers. AFM topographic images of same cells, both in water and in air-dry conditions, confirm this result. Measurements on thin sections allow quantitative results around $4.7 \%$ longitudinal shrinkage for G-layer.

Key words: cell wall, gelatinous layer, shrinkage, tension wood.

\section{INTRODUCTION}

\section{Longitudinal shrinkage in wood}

Like all other wood properties, hygroexpantion presents a very important anisotropy. Between green condition and ovendry condition, shrinkage ranges from $0.05 \%$ to $0.3 \%$ in longitudinal direction, $3 \%$ to $6 \%$ in radial direction and from $6 \%$ to $12 \%$ in tangential one (Skaar 1988). According to these values, the hygroexpension in axial direction is not apparently a problem for the user. However, two cases exist when longitudinal shrinkage starts to be more important: in reaction wood (tension wood of angiosperms and compression wood of gymnosperms) and juvenile wood (Skaar 1988). In these two types of wood, axial shrinkage can reach $1 \%$ or more (Nepveu 1994). For these woods, shrinkage value cannot be considered as negligible, because wood beams have generally their longer distances in axial direction. These important differences can be explained by the wood fibre structure. 


\section{From wood fibre structure to shrinkage modelling}

The knowledge of the wood cell structure, as a multi-layer fibre composite, allows the modelling of the longitudinal shrinkage.

One of the first models, which is still a reference, is the Barber and Meylan 's one (1964) refined by Barber (1968). This model considers that the cell wall is reduced to $S_{2}$ layer. $S_{2}$ layer is described like an amorphous hygroscopic matrix in which are imbedded parallel crystalline microfibrils which act to restrain hygroexpention in the direction parallel to their axes (Fig. 1) (Cave 1972a). Thus, microfibril angle is the determinant factor of longitudinal shrinkage. Low angle of microfibril in relation to axial direction induces low axial shrinkage (like in normal wood) and high angle allows a higher shrinkage (like in juvenile or compression wood). Later, other models integrating other components properties (cellulose, hemicellulose and lignin), changes in matrix behaviour during drying and introducing the different cell wall layers have been proposed to refine this first theory (Barrett et al. 1972; Cave 1972b, 1978; Sassus 1998; Gril et al. 1999; Yamamoto 1999).

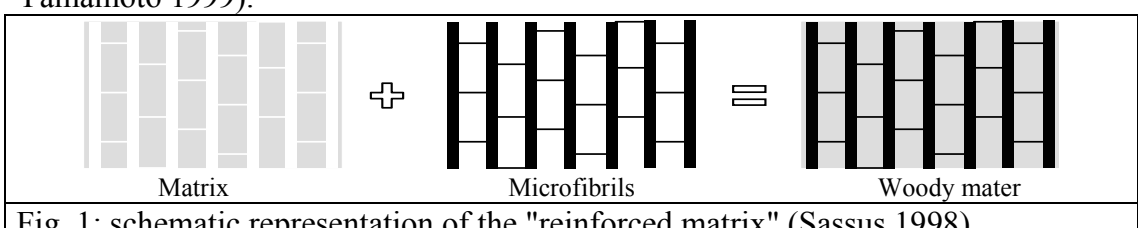

Fig. 1: schematic representation of the "reinforced matrix" (Sassus 1998)

These models give a good understanding of macroscopic axial shrinkage for different values of microfibril angle, for normal, compression and juvenile wood.

However, they cannot explain the behaviour of tension wood with gelatinous layer. In fact, in G layer, microfibril angle is very low or nil (Chaffey 2000), even when macroscopic longitudinal shrinkage is high (Clarke 1937; Chow 1946; Sassus 1998). Norberg and Meier (1966) had isolated portion of G layer and said that they do not show high longitudinal shrinkage. The $\mathrm{G}$ layer is generally loosened from $\mathrm{S}_{2}$ layer and this latter one is very thin in tension wood. So these authors and Boyd (1977) assume that in that case, longitudinal shrinkage is produced by $\mathrm{S}_{1}$ layer, $\mathrm{G}$ layer being unable to prevent it.

\section{MATERIAL AND METHODS}

One poplar (Populus cv I4551) and one beech (Fagus sylvatica L.), were chosen for this study. These species are known to have characteristic tension wood with G layer and a high macroscopic axial shrinkage.

\section{Populus cv I4551}

During the growing period, a young one year old poplar tree in a container is tilted $35^{\circ}$ from the vertical. At the end of that period, the stem has nearly regained its verticality by producing tension wood on the upper side (Fig. 2). Wood sample taken from this tension wood zone have characteristic anatomical features presenting a large amount of fibre with $G$ layer and very thin $\mathrm{S}_{2}$ layer (Fig. 4 A). 


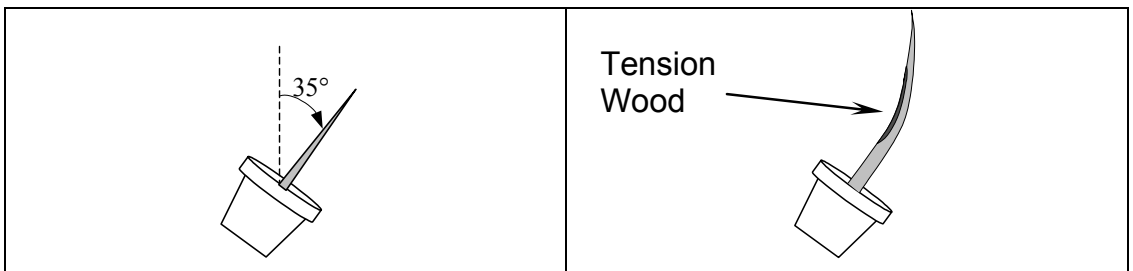

Fig. 2: Recovery of the verticality of a poplar stem after the container have been tilted $35^{\circ}$. Tension wood is produced on the upper side.

Fagus Sylvatica (L.)

A 150 years old tree was chosen after measurement of peripheral growth stresses at breast height level on the standing tree, on eight positions around the trunk. This tree was typical of a strongly dissymmetrical distribution of growth stresses (Fig. 3). A high local level of growth stress is always related to presence of tension wood (Trénard \& Guéneau 1975; Sassus 1994). Wood sample were taken around the highest values of growth stress ( $Z$ position on Fig. 3). In spite of large $G$ layer in the fibre cell wall, $\mathrm{S}_{2}$ layer remains thicker than in poplar wood (Fig. 4 B).

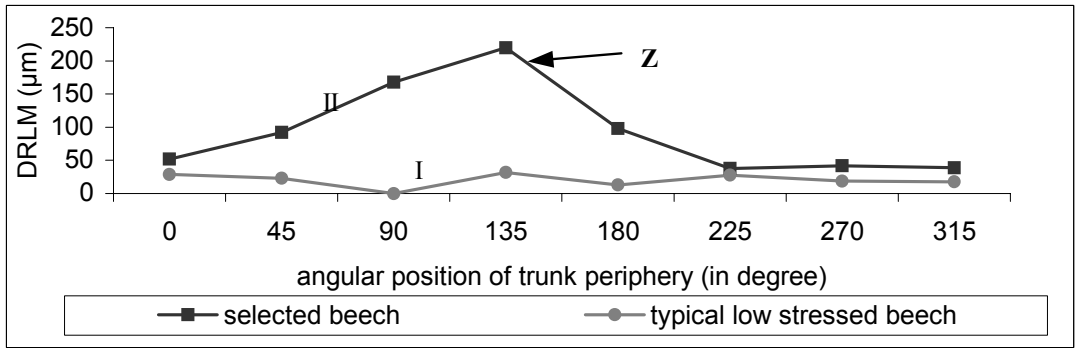

Fig. 3: Growth stress measurement on standing beech tree, on 8 angular positions of trunk periphery. I: tree with regular low levels of growth stress, II: tree with a zone (Z) of very high tensile growth stress.

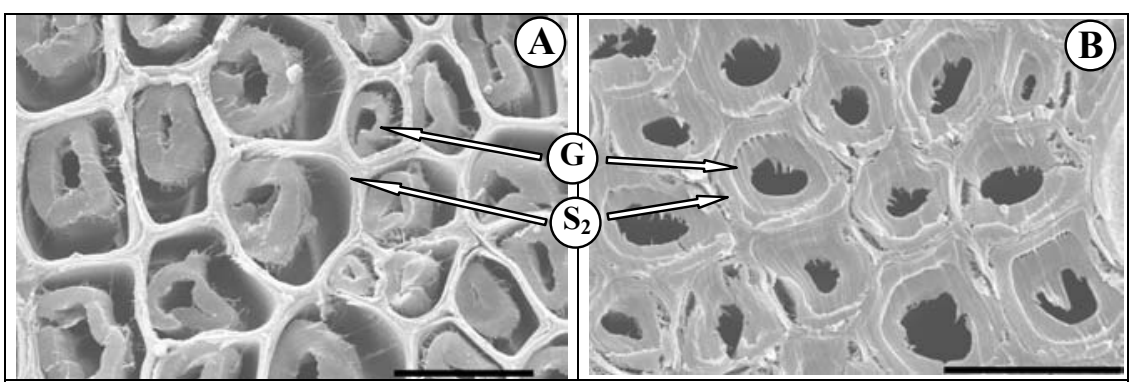

Fig. 4: SEM observation of poplar (A) and beech (B) with gelatinous layer (G) (also indicated $\mathrm{S}_{2}$ layer) (Scale bar: $20 \mu \mathrm{m}$ ) 
Wood samples were stored in green condition before further processing into small blocks or thin sections.

Massive blocks - Wood sticks ( $2 \mathrm{~cm}$ in longitudinal direction, section $5 \times 5 \mathrm{~mm}^{2}$ ) are cut up by splitting in order to guarantee a good axial direction. Sticks were then cut to obtain $5 \mathrm{~mm}$ size cubes. Finally a last superficial planning is done manually with a brand new razor blade in order to produce a nice transverse surface, the sample being always kept in moist condition.

Thin sections - Transverse sections, $80 \mu \mathrm{m}$ thick, were cut under water drop with a microtome equipped with disposable razor blade. These sections were glued on the edge with fibre direction parallel to support, in order to allow observations on transverse sections on both sides of the sample.

\section{Scanning electron microscopy}

Massive blocks or thin sections are dehydrated with absolute ethanol, passed to critical point and coated ( $300 \AA$ of platinum) before observation. Thus, observations are made in oven dry condition with a Cambridge S360 Scan Electron Microscope (Fig. 5).

The tilting of receptor allows to obtain images of a same object for different view angles.
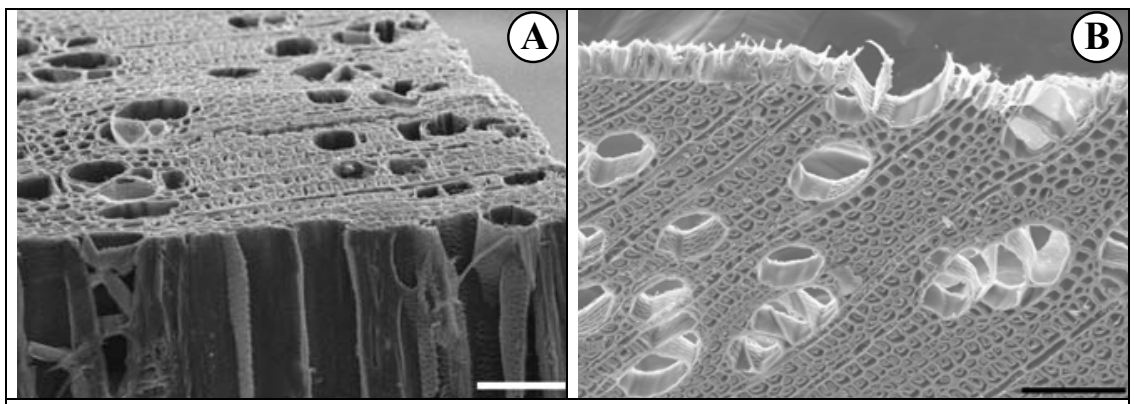

Fig. 5: SEM images of poplar: A massive bloc, B thin section; scale bars: $100 \mu \mathrm{m}$.

Atomic force microscopy

Smaller massive blocks $\left(500 \times 500 \times 500 \mu \mathrm{m}^{3}\right)$, prepared the same way as before, are observed in their transversal section in water and in air-dry condition. Four states are studied: green condition, green condition after 2 hours in $80^{\circ} \mathrm{C}$ water, air-dry conditions, wet conditions after air-drying. Atomic Force Microscope (Dimension 3100, Nanoscope IIIa, Digital Instruments) was used to obtain topographic images of a $50 \times 50 \mu \mathrm{m}^{2}$ area (around 10 cells). The same cells are observed successively in these conditions (Fig. 6). 


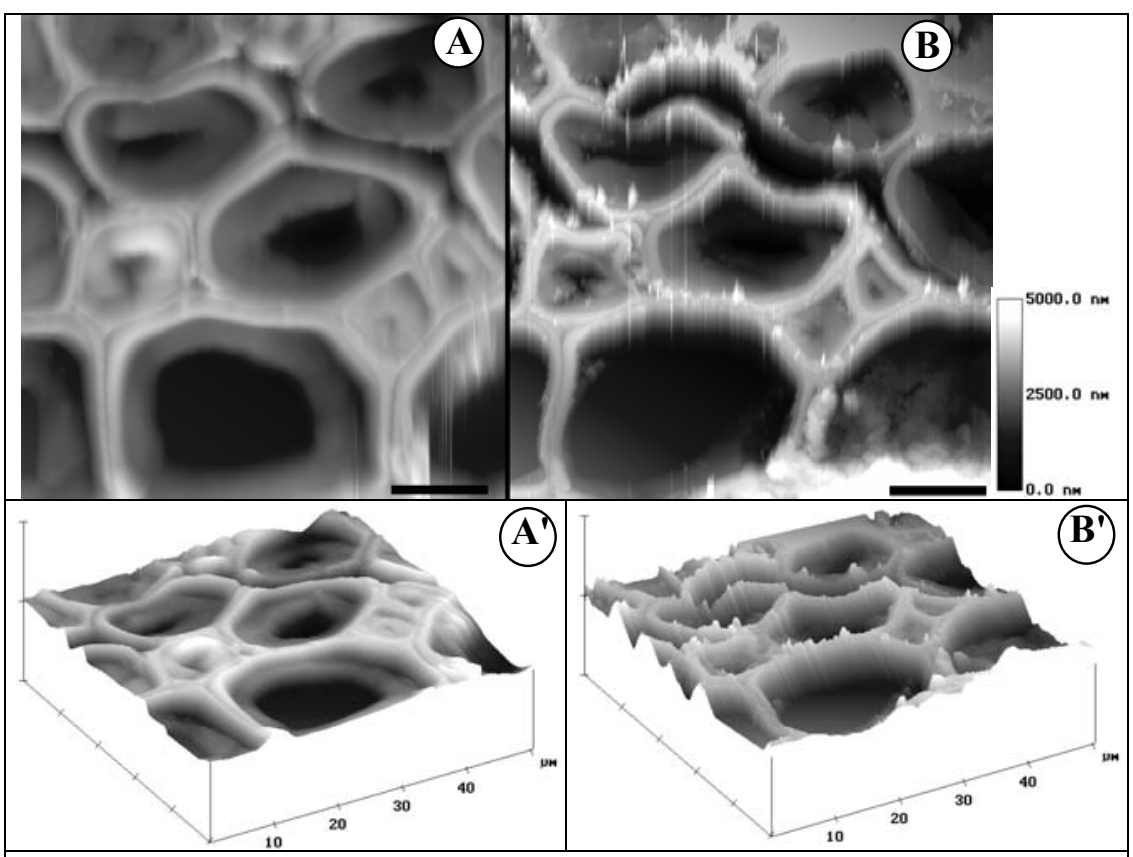

Fig. 6: AFM topographic images of same cells in water $\left(\mathrm{A}, \mathrm{A}^{\prime}\right)$ and in air-dry condition $\left(\mathrm{B}, \mathrm{B}^{\prime}\right)$. Scale bars: $10 \mu \mathrm{m}$.

\section{RESULTS}

\section{Scanning electron microscopy}

Massive blocs - Both in poplar and beech, one cell is observed with two angle of view, at first perpendicular to the surface and then tilted $70^{\circ}$ from that direction (Fig. 8). From these two images of a same cell, it is possible to draw a topographic profile of the cell after shrinkage (Fig. 8). The $\mathrm{x}$ coordinate is given directly by the first image while the y coordinate can be calculated with equation 1 using both images (Fig. 7).

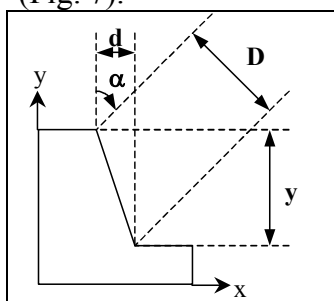

Equation 1:

$\mathrm{y}=\frac{\mathrm{D}}{\sin \alpha}-\frac{\mathrm{d}}{\tan \alpha}$

$\mathrm{d}$ is the measured distance on normal image, $\mathrm{D}$ on the titled $70^{\circ}$ image and $\alpha=70^{\circ}$

Fig. 7: Principle for calculation of topographic profiles 


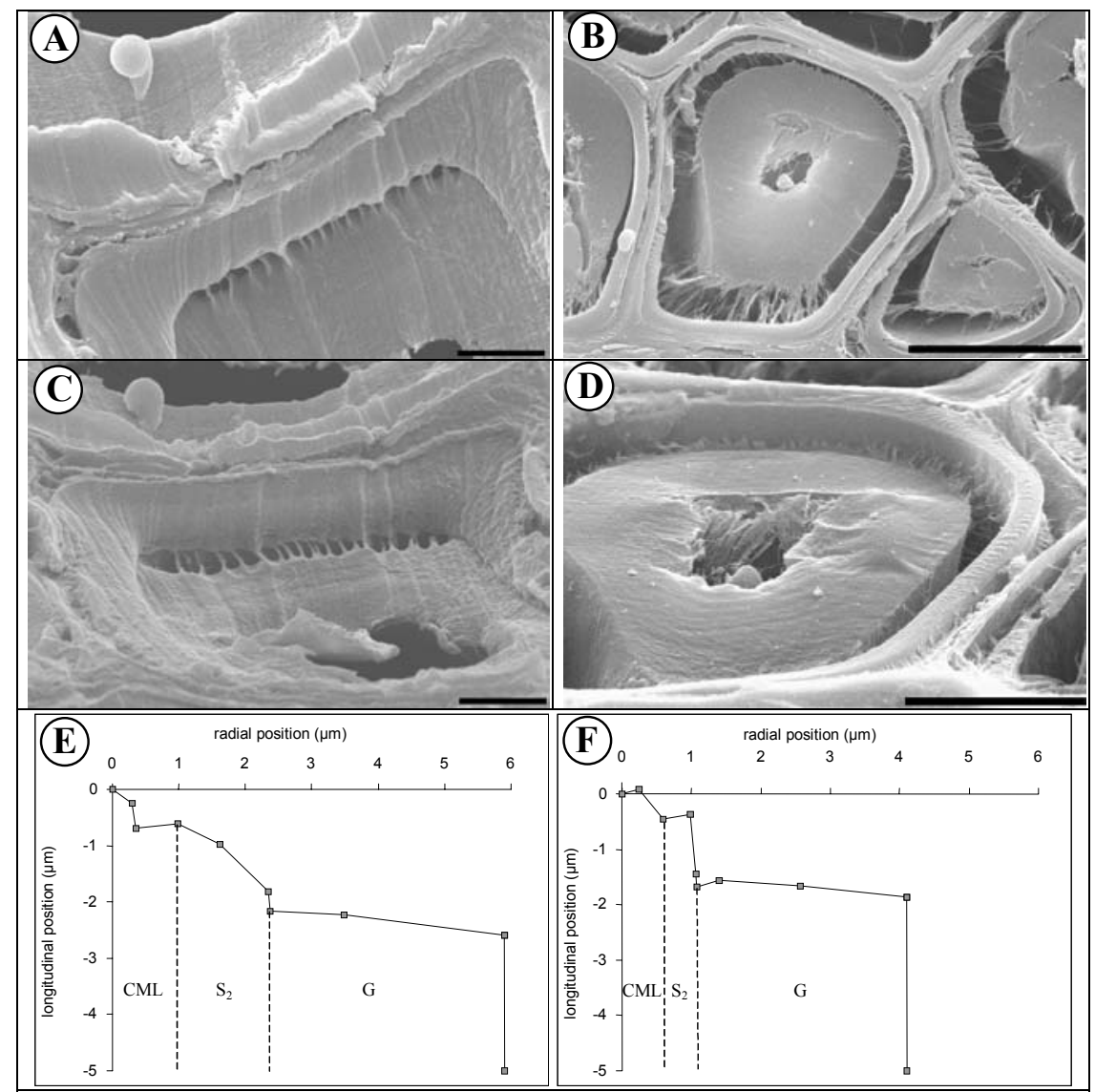

Fig. 8: SEM images and topographic profiles for one cell of beech (A, C, E) and poplar (B, D, F). A \& B: normal to surface images; C \& D: $70^{\circ}$ oblique images.

Scale bars: A \& C: $2 \mu \mathrm{m}$, B: $10 \mu \mathrm{m}$, D: $5 \mu \mathrm{m}$. (CML: compound middle lamella).

These topographic profiles allow measurements of differential shrinkage between cell wall layers. Notably, G layers are far more retracted than other layers (mean $2.2 \mu \mathrm{m}$ in beech and $2.8 \mu \mathrm{m}$ in poplar).

In $S_{2}$ layer of beech, it seems that there is a strain gradient between $S_{1}$ layer and $G$ layer, which is not the case for poplar.

These observations on massive blocks reveal a differential contraction between cell layers but do not allow quantitative estimation of actual shrinkage of these layers.

Thin sections — Several poplar cells were observed after drying. Restraint measurements have been made in the same cells in both faces of the section. To this 
aim, numerous images have been made with different scales and view angles to locate cells.

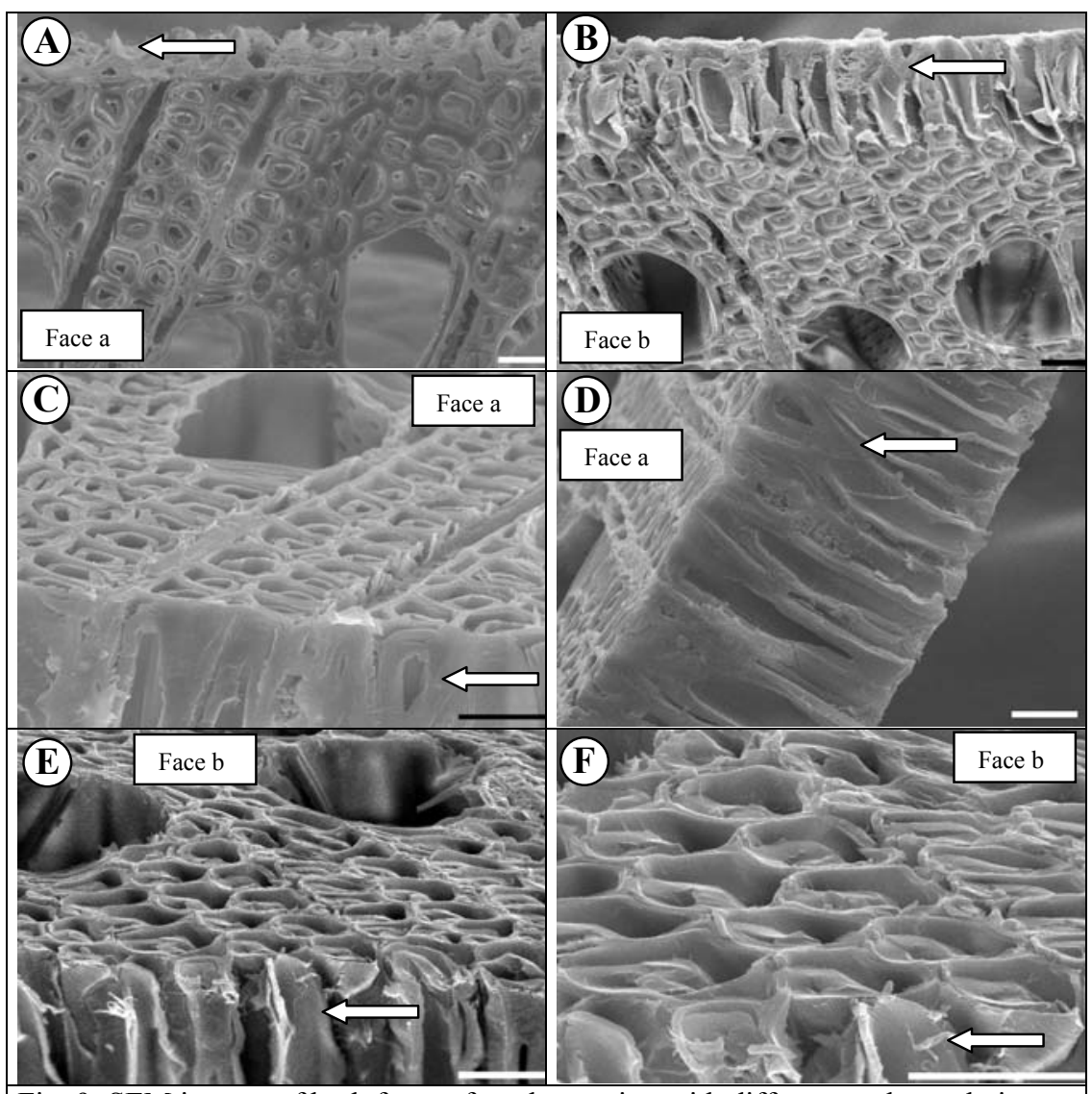

Fig. 9: SEM images of both faces of poplar section with different scales and view angles. Some cells on the edge (arrow) permit to locate all other. A \& C: face a, B, $\mathrm{E} \& \mathrm{~F}$ : face b. Measurements are made on images like F (Scale bars: $20 \mu \mathrm{m}$ ).

Results are presented in Fig. 10. Mean measurements of differential restraint between $\mathrm{G}$ layer and compound middle lamella (CML) are $1.99 \mu \mathrm{m}$ for a face, $1.83 \mu \mathrm{m}$ for the other and $3.82 \mu \mathrm{m}$ for the sum of faces. Thus, total G-layer differential shrinkage can be estimated from $3.6 \%$ to $5.8 \%$ with a mean value of $4.7 \%$ using the ratio between summation of both retrains and section thickness $(80 \mu \mathrm{m})$. 


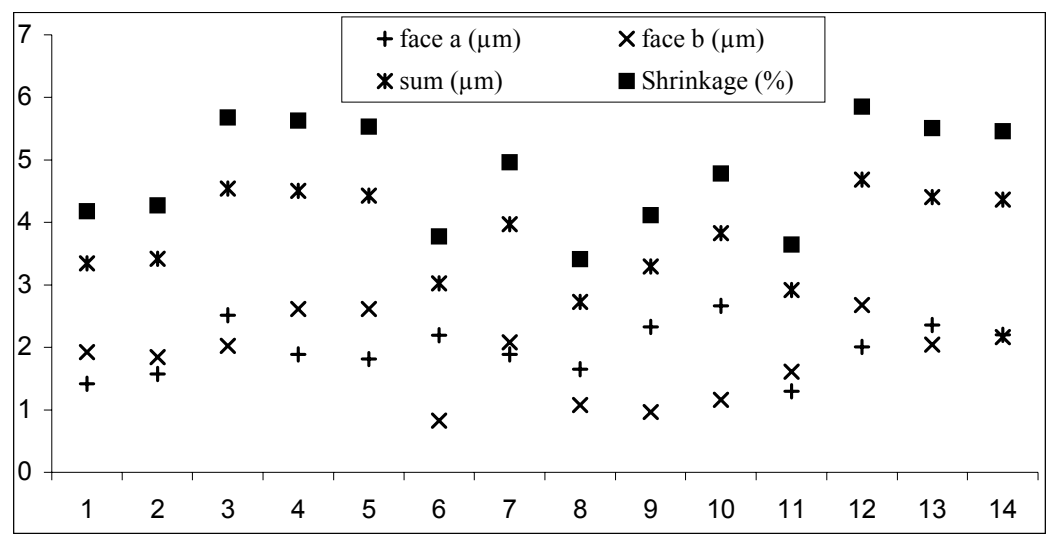

Fig. 10: differential restraints $(\mu \mathrm{m})$ and total shrinkage $(\%)$ of G-layer for 14 cells.

\section{Atomic force microscopy}

The profile in water (Fig. $11 \mathrm{~A}^{\prime}$ ) shows that there is already a small retract of Glayer before drying.

The profile in water after 2 hours in $80^{\circ} \mathrm{C}$ water (Fig. $11 \mathrm{~B}^{\prime}$ ) shows very few additional retract of G-layer before drying.

The profile in air-dry conditions (Fig. $11 \mathrm{C}^{\prime}$ ) confirms the presence of a more important shrinkage in G-layer than in other layers.

It can be noted also that, after drying, shrinkage is more important in middle lamella than in $\mathrm{S}_{2}$ layer.

The profile in wet conditions after air-drying (Fig. 11 D') shows a swelling of Glayer which allows it to almost recover its green condition position.

Another profile (not shown), in again air-dry conditions, shows the reversibility of the phenomenon. 


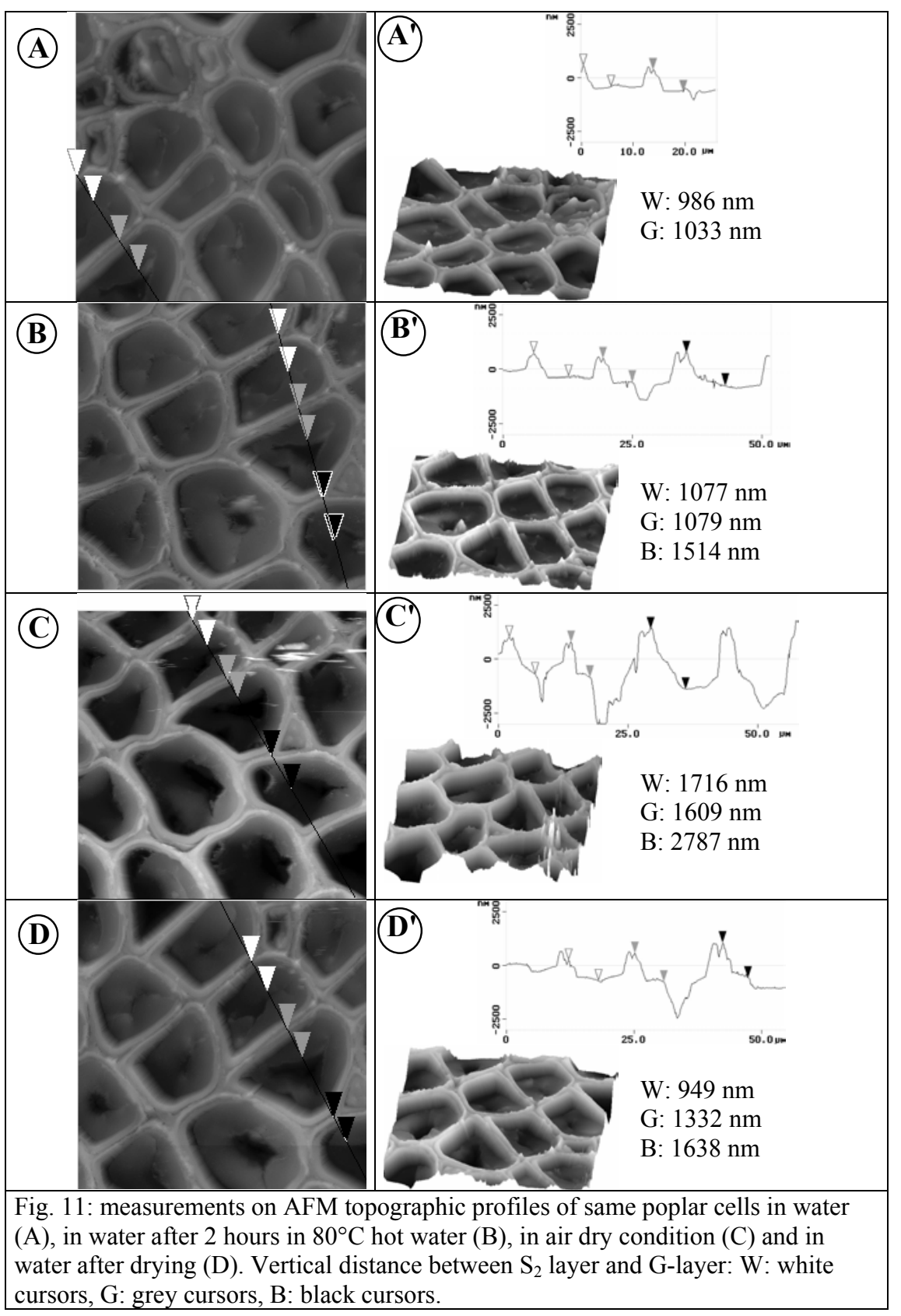




\section{DISCUSSION}

The first shrinkage observed in water with AFM method raises questions. It can be explained as a cutting artefact: during cutting, blade exerts a compression force on material. Thus, compliant parts (like middle lamella or $\mathrm{S}_{2}$ layer) are compressed when the blade is cutting, and stiff parts (like G-layer) are not (or even are pulled up). After the blade moving, due to recovery of these different stress states, softer and thinner layers lay above stiffer ones like the G-layer.

Another explanation can be derived from growth stress release. If G-layer is in a higher tensile stressed state than the other layers, crosscutting will be the origin of differential strain recovery which is measured here. Anyway both explanations can be true and generate a cumulative effect.

After drying, a higher differential longitudinal shrinkage can be observed in G layer. At the same time there is a high transverse shrinkage of this G-layer often leading to separation between G-layer and the remaining cell wall.

Again, it can be argued that this separation allows a more complete release of growth stress in the G-layer, so that, this further differential shrinkage is another expression of growth stress only.

Keeping a sample in hot water $\left(80^{\circ} \mathrm{C}\right)$ during two hours is known as a way to demonstrate viscoelastic and hygrothermal recovery of locked-in strains resulting from growth stresses (Gril \& Thibaut 1994). This can be observed only once after a first heating cycle resulting in a contraction or an expansion that can be the reverse of the usual thermal expansion (or sometimes contraction) which is a reversible classical phenomenon (Kübler 1987). In this case, the very low value of measured restraint seems to prove that the viscoelastic recovery, if any, mostly occurred before heating. Thus, hygroscopic shrinkage is the main phenomenon involved.

The swelling of G-layer in water after air-drying confirms the hypothesis of hygroexpansion of G-layer.

Thus, longitudinal shrinkage of G-layer can also be the origin of the strain gradient in beech $\mathrm{S}_{2}$ layer (Fig. 8). During the first drying phases, the G-layer is strongly adherent to $S_{2}$ layer and its shrinkage is the origin of high level drying stresses inside the $\mathrm{S}_{2}$ layer, inducing a contraction of this layer on the side of the G-layer until the layers' separation.

These observations of high longitudinal shrinkage in G-layer are contrary to the results of Norberg and Meier (1966), although it is rather difficult to measure strains of a few percent with photographs as these authors did. Thus, G-layer shrinkage, far to be negligible, could be the driving force of high macroscopic longitudinal shrinkage observed in tension wood. Longitudinal shrinkage of G-layer poses a problem for the understanding of observable fact. The G-layer structure, mainly composed of cellulose microfibrils with very low angle, does not permit to explain this shrinkage with models like Barber's one (1968). 
Even though transversal structure of G-layer is subject to controversy (Norberg \& Meier 1966; Côté et al. 1969; Faruya et al. 1970), these observations pose the problem of longitudinal arrangement of the cellulose microfibrils. Longitudinal shrinkage needs the presence of hygro-sensible zones. It seems that these zones, amorphous or disorganised (Yamamoto et al. 2000), would be inserted in crystalline cellulose zones (supposed insensible to humidity changes) both in axial and transversal directions.

\section{CONCLUSIONS}

Differential longitudinal shrinkage has been observed and measured on G-layer of beech and poplar tension wood. This study is in contradiction with Norberg and Meier results. Thus, numerous questions on G-layer structure are raised. Additional studies are needed to complete this result in order to understand the mechanisms of shrinkage in G-layer, and then, to understand macroscopic shrinkage in tension wood.

\section{ACKNOWLEDGEMENTS}

Many thanks for his patience, his availability and his interest to Michel Ramonda from the "Service Commun de Microscopie en Champ Proche" from Université Montpellier2.

We wish to thank Catherine Coutand from INRA for poplar samples.

Thanks to the staff of the "service commun de Microscopie électronique" from Université Montpellier 2

Thanks to Frederic Aliotti (student) for his help and his critical mind during the beginning of this research.

This work was performed in the frame of the concerted program "wood as a material" funded by ADEME and French Ministry of Agriculture.

\section{REFERENCES}

Barber, N.F. 1968. A Theoretical Model of Shrinking Wood. Holzforschung, 22: 97103.

Barber, N.F. \& B.A. Meylan. 1964. The anisotropic shrinkage of wood. A theoretical model. Holzforschung, 18: 146-156.

Barrett, J.D., A.P. Schniewind \& R.L. Taylor. 1972. Theoretical Shrinkage Model for Wood Cell Wall. Wood Science, 4: 178-192.

Boyd, J.D. 1977. Relationship between fibre morphology and shrinkage of wood. Wood Science and Technology, 11: 3-22.

Cave, I.D. 1972a. Swelling of a fibre reinforced composite in which the matrix is water reactive. Wood Science and Technology, 6: 157-161. 
Cave, I.D. 1972b. A Theory of the Shrinkage of Wood. Wood Science and Technology, 6: 284-292.

Cave, I.D. 1978. Modelling Moisture-Related Mechanical Properties of Wood. Part I: Properties of the Wood Constituents. Wood Science and Technology, 12: 75-86.

Chaffey, I. 2000. Microfibril orientation in wood cells: new angles on an old topic. Trends in Plant Sciences, 5: 360-362.

Chow, K.Y. 1946. A comparative study of the structure and composition of Tension Wood in Beech (Fagus sylvatica L.). Forestry, 20: 62-77.

Clarke, S.H. 1937. The distribution, structure and properties of tension wood in beech (Fagus sylvatica L.). Journal of Forestry, 11: 85-91.

Côté, W.A.J., A.C. Day \& T.E. Timell. 1969. A contribution to the ultrastructure of tension wood fibers. Wood Science and Technology, 3: 257-271.

Faruya, N., S. Takahashi \& H. Miazaki. 1970. The chemical composition of the gelatinous layer from the tension wood of Populus euramericana. Journal Japanese of Wood Reaserch Society, 16: 26-30.

Gril, J., F. Sassus, H. Yamamoto \& D. Guitard. 1999. Maturation and drying strain of wood in longitudinal direction: a single-fibre mechanical model. In: G. Nepveu (Editor), 3rd Workshop on Connection between silviculture and wood quality through modelling approaches and simulation softwares (IUFRO WP S5.01.04 "Biological Improvement of Wood Properties"). ERQB-INRA Nancy, La Londe-Les-Maures, pp. 309-313.

Gril, J. \& B. Thibaut. 1994. Tree mechanics and wood mechanics: relating hygrothermal recovery of green wood to the maturation process. Annales des Sciences Forestières, 51: 329-338.

Kübler, H. 1987. Growth stresses in trees and related wood properties. Forest Products Abstracts, 10: 61-119.

Nepveu, G. 1994. Variabilité. In: A.R.BO.LOR (Editor), Le Bois, Matériau d'Ingénierie, Nancy, pp. 127-182.

Norberg, P.H. \& H. Meier. 1966. Physical and chemical properties of the gelatinous layer in tension wood fibre of aspen (Populus tremula L). Holzforschung, 20: $174-178$.

Sassus, F. 1994. Déformations de maturation et morphologie chez le clone de peuplier I214. In: B. Thibaut (Editor), 7ème Séminaire Architecture, Structure et Mécanique de l'Arbre. LMGC, Université Montpellier 2, Montpellier, pp. 159-166.

Sassus, F. 1998. Déformations de maturation et propriétés du bois de tension chez le hêtre et le peuplier : mesures et modèles. Sciences du bois Thesis, ENGREF, Montpellier.

Skaar, C. 1988. Wood-Water Relations. In: T.E. Timell (Editor), Springer Series in Wood Science. Springer-Verlag, Berlin Heidelberg, pp. 283.

Trénard, Y. \& P. Guéneau. 1975. Relations entre contraintes de croissance longitudinales et bois de tension dans le hêtre (Fagus sylvatica L.). Holzforschung, 29: 217-223. 
Yamamoto, H. 1999. A model of anisotropic swelling and shrinking process of wood. Part 1. Generalization of Barber's wood fiber model. Wood Science and Technology, 33: 311-325.

Yamamoto, H., N. Soma, T. Okuyama \& J. Gril. 2000. Origin of Mechanical Properties of Wood Related to the Composite structure of the multi-layered cell wall, 3rd Plant Biomechanics Conference. Thieme-Verlag, Badenweiler (Freiburg), Germany. 